\title{
Margaret Gladys Smith, mother of cytomegalovirus: 60th anniversary of cytomegalovirus isolation
}

\author{
Matthias J. Reddehase ${ }^{1}$
}

Received: 27 March 2015 / Accepted: 29 March 2015 / Published online: 12 April 2015

(C) Springer-Verlag Berlin Heidelberg 2015

In the year 2014, the 'cytomegalovirus community' of researchers commemorated the 60th anniversary of cytomegalovirus isolation by Margaret Gladys Smith (18961970), former faculty member and Professor of Pathology at the Washington University in St. Louis, School of Medicine (Fig. 1). The year 1954 brought a number of chronicle events: the 'birth' of cytomegalovirus in Saint Louis/ Missouri, a total solar eclipse, the 'Niagara rock fall', the 'miracle of Bern,' and, last and least, a baby boy was born in the Bavarian Alps for whom the scientific achievements by Margaret Gladys Smith should become sort of destiny.

Histopathological alterations characteristic of infection by an agent now known as cytomegalovirus, namely enlarged 'cytomegalic' cells with intranuclear inclusions, were first observed by the pathologist Dr. Ribbert in sections of the kidney of a stillborn presenting with Lues-like symptoms and interstitial nephritis. The "cradle of cytomegalovirus' is Dr. Ribbert's case report given at a meeting of the medical section of the Natural History Society of Prussian Rhineland and Westphalia, held on June 27, 1881, in Bonn, Germany [1]. After a period when cytomegalic cells were mistaken for protozoa, specifically for Gregarines, ([2], see also [3]), von Glahn and Pappenheimer were first to propose a viral etiology of the intranuclear inclusions associated with visceral disease [4]. In 1950, Wyatt et al. [5] coined the figurative name 'cytomegalic inclusion disease (CID)' for the clinical manifestations in newborns after congenital infection, though a

Matthias J. Reddehase

matthias.reddehase@uni-mainz.de

Institute for Virology, Research Center for Immunotherapy (FZI), University Medical Center of the Johannes Gutenberg-University Mainz, Mainz, Germany



Fig. 1 Margaret Gladys Smith in the late 1960s as 'professor emerita active,' lecturer in the Department of Pathology at Washington University School of Medicine. It was the time when she co-authored the classic textbook Pathology of Infancy and Childhood with John M. Kissane. For more details of her biography, use the website Women in Health Sciences (http://beckerexhibits.wustl.edu/mowihsp/bios/smith. htm). Photograph from the Bernhard Becker Medical Library Image Gallery (identifier VC410SmithMG02) 


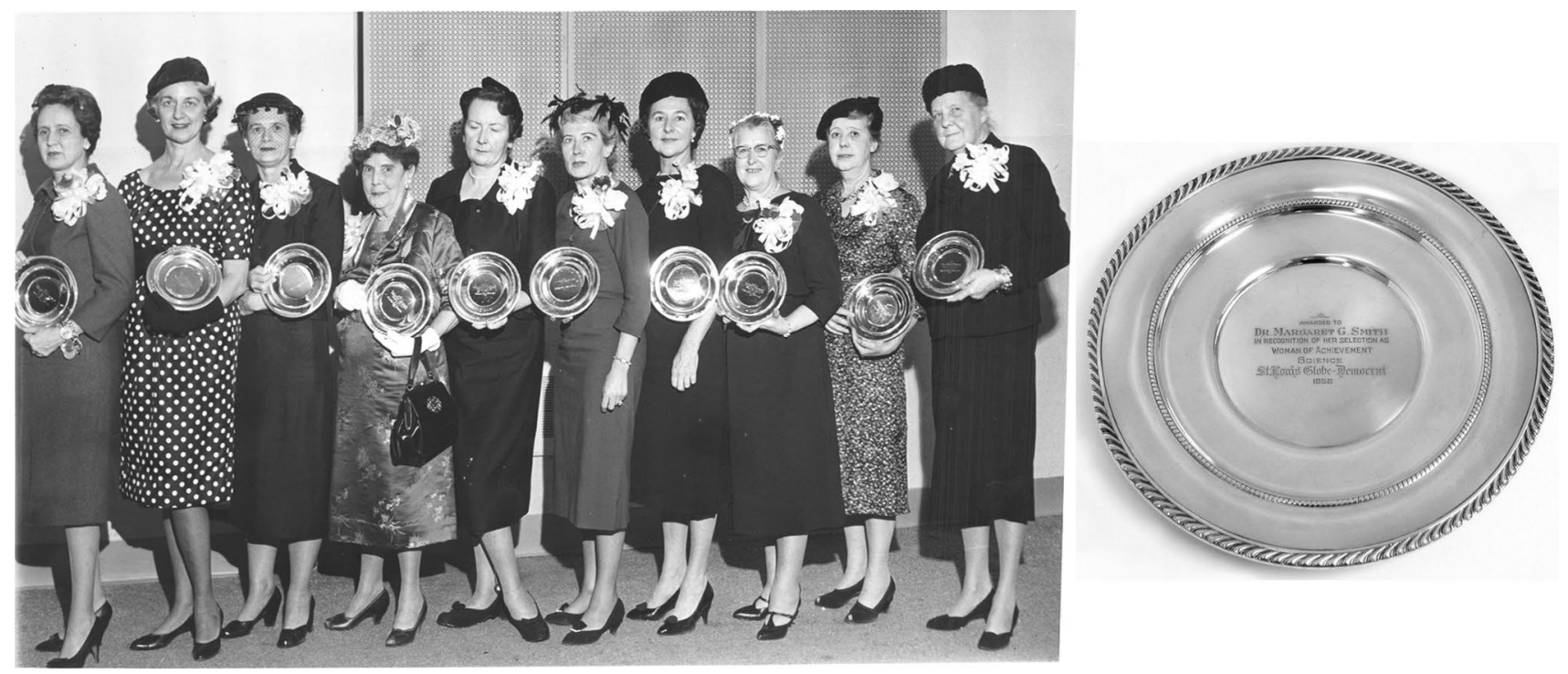

Fig. 2 Time journey back to the Saint Louis of the 1950s. The Saint Louis Globe-Democrat (the daily newspaper popularly known as 'The Globe') honored Dr. Margaret G. Smith as one of its 1958 Women of Achievement for her contributions in Science. The award ceremony, held in January 1959, paid 'tribute to the ten women

viral etiology was not confirmed until 1953, when Minder [6] saw 199-nm particles in cytomegalic pancreatic cells during electron microscopic analysis of tissue specimens from a case of CID (for a more comprehensive history of cytomegaloviruses and its diseases, see the contribution by the late Monto Ho to a previous MMI Special Issue: Cytomegalovirus, published under the same guest editorship [7]) (Fig. 2).

The turn of eras from descriptive science to research into pathomechanisms and interventional strategies was only made possible by getting access to the virus, and this is the merit of Margaret Gladys Smith (Figs. 2 and 3). In 1954, she first succeeded in isolating murine cytomegalovirus from salivary glands of mice and propagating it in cell culture of murine cells [8], the prototype strain named after her and still in use as the 'Smith strain' (Fig. 4). Soon thereafter, in 1955, she also succeeded in growing submaxillary salivary gland-derived human cytomegalovirus in human cell culture, but her submitted manuscript was rejected because the editors suspected she accidentally might have grown the murine virus on the human cells. She reproduced her pioneering findings with the kidney of a 1-month-old infant, who died of CID, as the clinical source of the virus, and eventually published the propagation of human cytomegalovirus in human cell culture in 1956 [9], back-to-back with a similar report by Rowe et al. [10]. selected for their outstanding contribution to betterment of our way of life during 1958.' The honorees each received a sterling silver bowl. Guess who she is!? Simply look for the nicest lady! Photographs and part of the text from the Bernhard Becker Medical Library Image Gallery (identifiers VC023001 and VC023118)

She introduced her paper on the propagation of human cytomegalovirus [9] with the words:

It is now well recognized that there exist in man, monkeys and several rodents closely related viruses, which lie dormant in the salivary glands, but are capable of causing fatal generalized infections with visceral necrosis. A general term for these agents is salivary gland virus (SGV). Each virus or strain of the virus is probably species-specific, since all attempts to infect animals of one species with virus derived from another species have failed.

Thus, besides her outstandingly important achievement of growing cytomegaloviruses in cell culture, Margaret Gladys Smith deserves to be honored for having recognized the host species-specificity of cytomegaloviruses, a phenomenon revisited from a molecular view in this issue of MMI in the contribution by Wolfram Brune's group.

Standing in the scientific tradition of Margaret Gladys Smith, the team of authors of this special issue is proud to present current research on cytomegaloviruses, clinical research as well as primate and rodent models, starting with Stanley Plotkin's 'special guest' synopsis of trials and progress in the development of a cytomegalovirus vaccine, followed by 20 articles ranging from current clinical topics to the cell biology and immunology of cytomegaloviruses. 


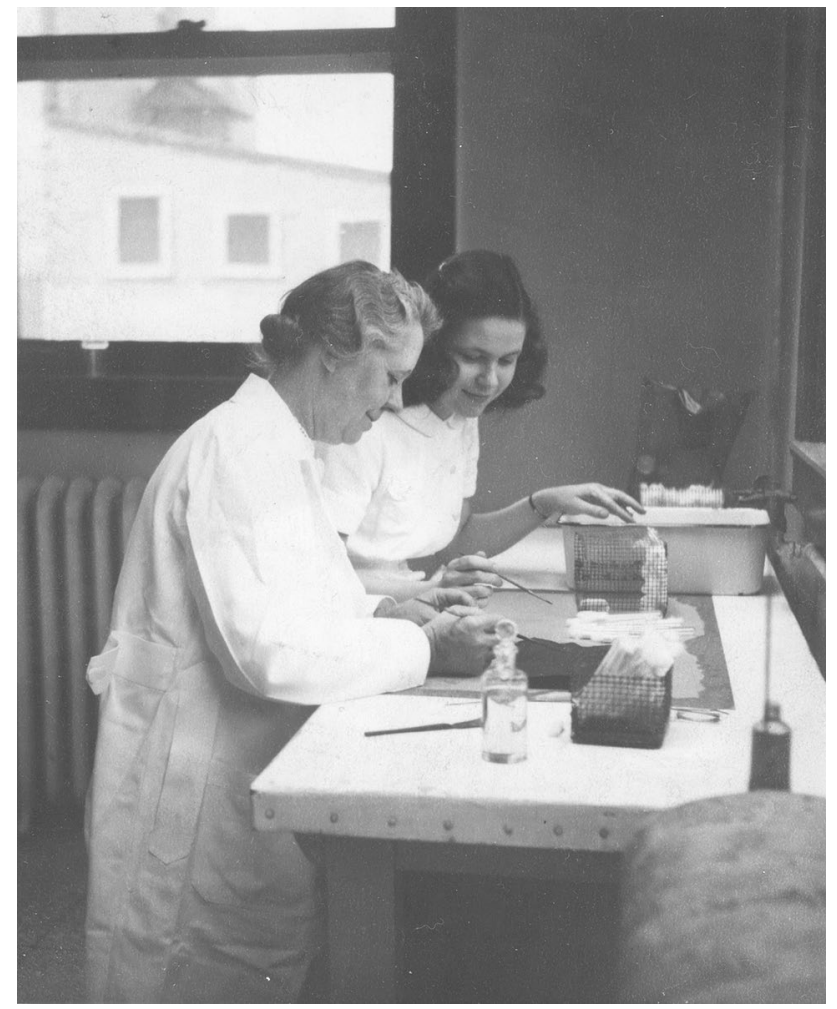

Fig. 3 Margaret Gladys Smith with a young lady student during one-on-one teaching at the bench. Dr. Smith was the first woman to hold an administrative position in the Washington University School of Medicine. In recognition of her dedication to women in medicine, the medical faculty established the Dr. Margaret G. Smith Award to be given to a female student for outstanding achievement in the first two years of medical school. Photograph and part of the text from the Bernhard Becker Medical Library Image Gallery (identifier VC023054)

With this, I hand over to Dr. Edward S. Mocarski, who will introduce Dr. Stanley A. Plotkin.

Acknowledgments High-resolution photographic images of Margaret Gladys Smith from the Bernhard Becker Medical Library Image Gallery were kindly provided by Philip Skroska, archivist of the Visual and Graphic Archives, and reproduced with permission by the Bernhard Becker Medical Library, Washington University School of Medicine, Saint Louis, Missouri. I thank Dr. Edward S. Mocarski, Emory University School of Medicine, Atlanta, and Dr. Fred A. Murphy, University of Texas, Galveston, for their help with finding archive material on Margaret Gladys Smith.

\section{References}

1. Andrä CJ (ed) (1881) Verhandlungen des naturhistorischen Vereines der preussischen Rheinlande und Westfalens. Achtunddreissigter Jahrgang. Vierte Folge: 8. Jahrgang, Max Cohen \& Sohn, Bonn, pp 161-162

2. Jesionek A, Kiolemenoglou B (1904) Ueber einen Befund von protozoenartigen Gebilden in den Organen eines hereditaerluetischen Foetus. Muenchner Med Wochenschr 51:1905-1907

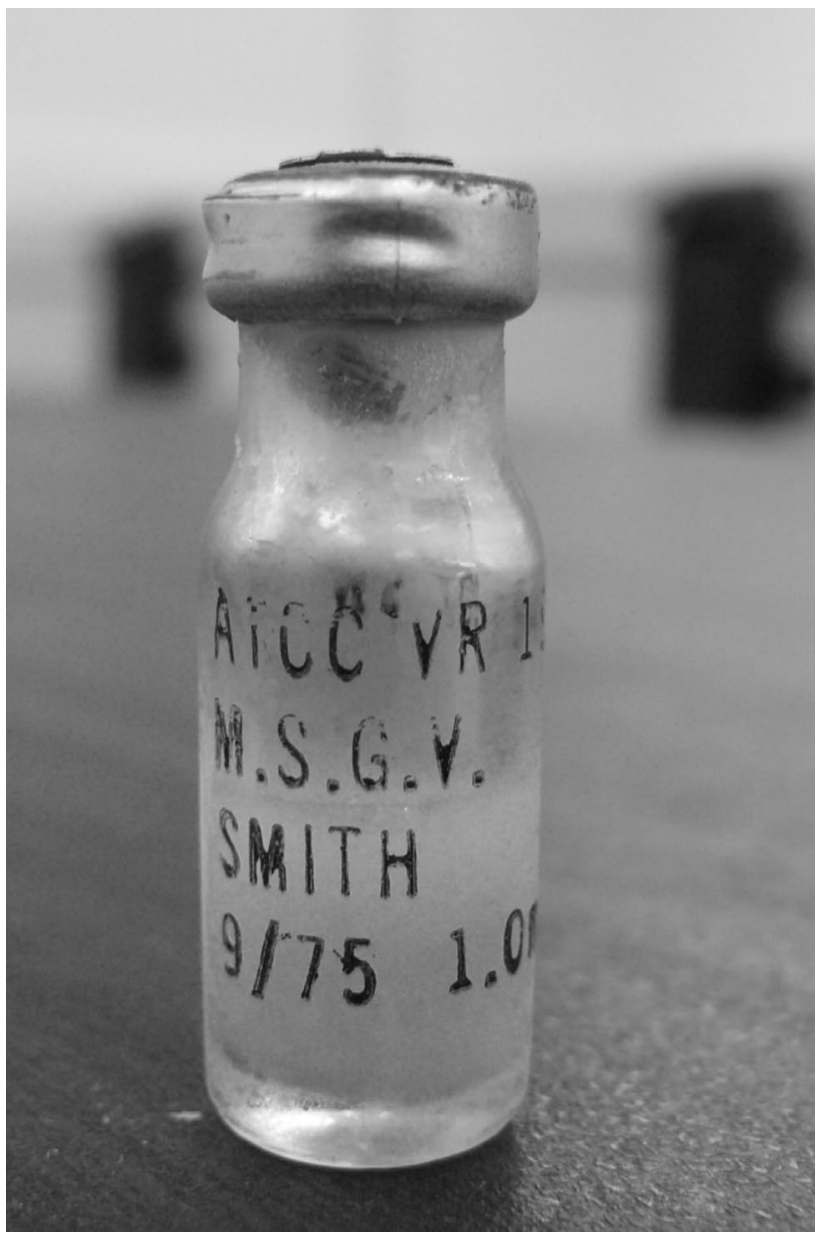

Fig. 4 The last of its kind. Probably the last still existing 'viable' vial of mouse salivary gland virus (M.S.G.V.) SMITH, ATCC VR-194 batch of 9/75, distributed by the American Type Culture Collection. Photograph by courtesy of its guardian Dr. Günther Keil, FriedrichLoeffler-Institut (FLI), Federal Research Institute for Animal Health, Greifswald-Insel Riems, Germany

3. Reddehase MJ (2006) Preface: from protozoan to proteomics. In: Cytomegaloviruses: molecular biology and immunology. Caister Academic Press, Norfolk, UK, pp xxiii-xxvii

4. von Glahn WC, Pappenheimer AM (1925) Intranuclear inclusions in visceral disease. Am J Pathol 1:445-465

5. Wyatt JP, Saxton J, Lee RS, Pinkerton H (1950) Generalized cytomegalic inclusion disease. J Pediatr 36:271-294

6. Minder WH (1953) Die Aetiologie der Cytomegalia infantum. Schweizer Med Wochenschr 83:1180-1182

7. Ho M (2008) The history of cytomegalovirus and its diseases. Med Microbiol Immunol 197:65-73

8. Smith MG (1954) Propagation of salivary gland virus of the mouse in tissue cultures. Proc Soc Exp Biol Med 86:435-440

9. Smith MG (1956) Propagation in tissue cultures of a cytopathogenic virus from human salivary gland virus (SGV) disease. Proc Soc Exp Biol Med 92:424-430

10. Rowe WP, Hartley JW, Waterman S, Turner HC, Huebner RJ (1956) Cytopathogenic agent resembling human salivary gland virus recovered from tissue cultures of human adenoids. Proc Soc Exp Biol Med 92:418-424 